\title{
Pemanfaatan Pemasaran Online Penjualan Telur Asin di Kabupaten Brebes
}

\author{
The use of Online Marketing Sales Salted Egg in the District of Brebes
}

Oleh:

\author{
Muhammad Syaifulloh'); Suci Nur Utami²); Slamet Bambang Riono3); Azizah Indriyani ${ }^{4)}$ \\ Prodi Manajemen Universitas Muhadi Setiabudi1;3,4) \\ Prodi Agribisnis Universitas Muhadi Setiabudi2) \\ msyaifulloh@umus.ac.id ${ }^{1}$, sucinurutami@umus.ac.id²), sbriono@umus.ac.id ${ }^{3)}$, \\ azizahindriyani@gmail.com ${ }^{4}$
}

\begin{tabular}{llll}
\hline Submit: 29 Nov $2020 \quad$ Review: 07 Dec $2020 \quad$ Accept: 30 May $2021 \quad$ Publish: 31 May 2021
\end{tabular}

\begin{abstract}
ABSTRAK
Usaha telur asin ini semakin berkembang dan terkenal tidak hanya oleh masyarakat Brebes namun juga oleh masyarakat yang berasal dari luar daerah Brebes. Transaksi bisnis melalui Online merupakan satu fenomena bisnis baru. Dari sisi finansial, pemasaran online sangat menjanjikan untuk peningkatan laba usaha, Penelitian ini mempunyai tujuan untuk menganalisis Kegiatan Pemanfaatan Pemasaran Online Penjualan Telur Asin dikabupaten Brebes. Jumlah Populasi dan sampel dalam penelitian ini adalah 30 Pedagang Telor asin yang sudah memanfaatkan jual beli Online dikabupaten brebes. Penelitian dilakukan dengan menggunakan metode deskriptif dengan pendekatan kualitatif. Data diambil dengan menggunakan wawancara melalui bantuan kuesioner, observasi, dan dokumentasi. Informan didapat dari beberapa produsen telur asin di Kabupaten Brebes dan konsumen yang mengkonsumsi telur asin. Hasil penelitian menunjukkan bahwa produsen telur asin online di Kabupaten Brebes telah melakukan seluruh tahapan proses dalam kegiatan promotion mix. Produsen/produsen telah melakukan periklanan online, sales promotion, direct marketing, dan personal selling dengan baik. Produsen telur asin telah memanfaatkan media online diantaranya website, blog maupun social media namun sebagian dari produsen masih memiliki keterbatasan pengetahuan dalam pemanfaatan media online tersebut.
\end{abstract}

Kata Kunci : Pemasaran Online; telur asin; Kabupaten Brebes

\section{ABSTRACT}

This salted egg business is growing and is famous not only by the people of Brebes but also by people who come from outside the Brebes area. Online business transactions are a new business phenomenon. From a financial perspective, online marketing is very promising to increase operating profit. This study aims to analyze the Utilization of Online Marketing Activities for Selling Salted Eggs in Brebes Regency. The number of population and samples in this study were 30 salted egg traders who have used online buying and selling in Brebes regency.The research was conducted using a descriptive method 
with a qualitative approach. Data were collected using interviews with the help of questionnaires, observation, and documentation. Informants were obtained from several salted egg producers in Brebes Regency and consumers who consume salted eggs. The results showed that the online salted egg producers in Brebes Regency had carried out all stages of the process in the promotion mix activity. Producers / producers have carried out online advertising, sales promotion, direct marketing, and personal selling well. Salted egg producers have used online media including websites, blogs and social media, but some of the producers still have limited knowledge in the use of online media.

\section{Keywords: Online Marketing, Salted Eggs, Brebes Regency}

\section{PENDAHULUAN}

Pemasaran sangat penting bagi semua bisnis, tidak memandang bisnis tersebut besar maupun kecil. Apabila dalam suatu bisnis tidak adanya pemasaran, maka konsumen tidak akan mengetahui tentang sebuah produk yang dihasilkan dari bisnis tersebut dan membuat penjualannya menjadi rendah. Di era teknologi yang terus berkembang pesat seperti sekarang ini, model pemasaran dapat menerapkan suatu teknologi yang dapat dengan cepat dan bisa menjangkau konsumen lebih luas dalam waktu yang singkat dan tentu saja dengan dana pemasaran yang tidak terlalu besar. Seorang penjual dapat menerapkan suatu cara pemasaran dengan memanfaatkan media elektronik yang lebih efisien dan murah yaitu internet.

Perubahan yang cepat dan signifikan di bidang teknologi, telekomunikasi, dan digitalisasi di era industri 4.0 telah menjadi sebuah keniscayaan. Perubahan tersebut memaksa adanya perubahan pada setiap pelaku untuk beradaptasi dengan perkembangan ekonomi global (Hasdar, Fera, \& Syaifulloh, 2019) Kemajuan teknologi yang berlangsung sangat cepat telah mendorong perusahaan untuk melakukan praktek pemasaran dan bisnis yang baru. Media Online sebagai elemen dari perkembangan teknologi, secara menggemparkan telah membentuk bisnis baru. Konsumen di seluruh lapisan masyarakat telah ditunjukan akan cara hidup dan konsumsi yang baru dan menginginkan banyak hal yang telah mereka lihat diberanda. Yang akahirnya Bisnis juga mulai mengadopsi Daring/internet sehingga mendukung terciptanya system Bisnis e-commerce, education, e-marketing, dan lainnya. (Eva, 2007)

Transaksi bisnis melalui internet merupakan satu fenomena bisnis baru. Salah satu manfaat internet sebagai saranamemperkenalkan dan memasarkan produkbarang atau jasa. Dari sisi finansial, pemasaran online sangat menjanjikan untuk peningkatan laba usaha (Setiawati, 2017). Pemasaran online secara bersamaan dapat mempengaruhi proses informasi promosi dan iklan produk oleh para pengguna internet/Netizen. Hal ini dimaksudkan supaya bisa terjadi sebuah pelayanan kepada konsumen tanpa membutuhkan banyak tenaga pemasar atau Sumber Daya Manusia (Wandanaya, 2012).

Produksi dan penjualan Telor asin di kabupaten brebes sangat melimpah, bahkan brebes dijuluki sebagai kota telu asin, tetapi dengan banyaknya pedagang dengan cara konvensioal, menyebabkan persaingan semakin ketat.sehingga beberapa toko telur asin yang namanya kurang dikenal akan tersisih atau berkurang pendapatannya. Dengan model 
pemasaran online di harapkan bisa menambah penghasilan mereka dengan memajang harga yang bersaing.

Komunikasi pemasaran dapat dilakukan dalam beragam jenis. Namun, kegiatan Promosi Penjualan maupun periklanan adalah bentuk komunikasi yang paling dikenal masyarakat. (Sutedjo \& Oetomo, 2015) Kabupaten Brebes terkenal dengan produk unggulanya seperti telur asin, batik tulis dan bawang merah namun pemasaranya masih konvensional melalui transaksi klasik (Rais, 2019) sedangkan Pembangunan jalan tol Pejagan-Brebes Timur tentunya memiliki dampak bagi Kabupaten Brebes baik pengaruh positif maupun negatif. Salah satu dampak negatif yang diterima oleh Kabupaten Brebes khususnya bagi pelaku Usaha Mikro Kecil dan Menengah (UMKM) adalah menurunnya omset penjualan hasil unggulan daerah, seperti telur asin, dan bawang merah. (Ikhwan \& Nugroho, 2019) Sehingga Alternatif Pemanfaatan Pemasaran Online menjadi Alternatif Penjualan yang efektif

Brebes merupakan daerah yang potensial dalam pembuatan telur asin. Sebagai sentral produksi telur asin, Brebes sebenarnya memiliki akar sejarah yang tidak dilepaskan dari budaya yang melahirkan ketrampilan membuat makanan ringan seperti telur asin itu sendiri. perkembangan sector makanan dan minuman di masyarakat umumnya tidak terlepas dari meningkatnya minat masyarakat akan adanya berbagai variasi olahan makanan. (Primatami \& Primadhita, 2020)

Usaha telur asin ini semakin berkembang dan terkenal tidak hanya oleh masyarakat Brebes namun juga oleh masyarakat yang berasal dari luar daerah Brebes(Amrillah, 2013). Tetapi karena Penjualan masih Tradisional dengan membuka toko, maka penghasilan masih belum maksimal, di zaman teknologi ini sudah ada sebagain pedagang yang sudah memulai pemasaran dengan modern, yaitu dengan cara melalui Media Online, oleh karena itu peneliti teratrik meniliti tentang Pemanfaatan Pemasaran Penjualan Telor asin di kabupetan Brebes.

\section{METODE PENELITIAN}

Metode yang digunakan dalam penelitian ini adalah metode deskriptif dengan pendekatan kualitatif. Penggunaan metode desktiptif dengan pendekatan kualitatif dalam penelitian ini bertujuan untuk mendapatkan pemahaman yang sebenar-benarnya mengenai fakta yang ada di lapangan yang didasarkan pada data-data yang bersifat diskursif seperti transkrip dokumen, catatan lapangan, hasil wawancara, dan dokumen tertulis. (Nurrochmawati et al., 2017).

Jumlah Populasi dalam Penelitian ini yaitu pedangan Telor asin di Kecamatan Brebes dan Kecamatan Wanasari kabupten Brebes yang sudah memanfaatkan media online yaitu 30 pedagang, adapun jumlah sampel sama dengan populasi yaitu 30 pedagang yang dihitung dengan metode sensus/Total sampling., Sampel adalah bagian (subset) dari populasi yaitu sejumlah orang, peristiwa, benda, atau obyek tertentu yang dipilih dari populasi untuk mewakili populasi tersebut (Heru Mulyanto, 2010)

Penelitian dilakukan dengan melakukan wawancara terhadap beberapa orang informan. Informan diambil secara purposive terhadap produsen telur asin yang ada di Kabupaten Brebes yang dapat memberikan informasi cukup akurat terkait penelitian ini. Pengumpulan data dengan menggunakan bantuan kuesioner, 
observasi, serta dokumentasi. Penelitian dilaksanakan secara aktual, faktual, dan sistematis mengenai keabsahan data-data yang ditemukan di lapangan. Peneliti juga mengambil informasi dari beberapa konsumen telur asin yang secara langsung mengkonsumsi produk telur asin.

Data dalam penelitian ini dianalisis dengan menggunakan model analisis data interaktif Miles dan Huberman melalui tiga proses interaktif yaitu reduksi data dengan memilih, memfokuskan, menyederhanakan, dan mengabstraksi data dari berbagai sumber melaui proses wawancara dan observasi. Proses selanjutnya adalah penyajian data dengan merakit data serta menyajikan data dengan baik agar lebih mudah dipahami. Data dapat disajikan dalam bentuk matriks, gambar/skema, jaringan kerja, tabel atau yang lainnya. Proses terakhir adalah dengan menarik kesimpulan dari pengujian yang telah dilakukan. Penarikan kesimpulan awal dipertajam dengan melakukan revisi dan penajaman analisis dan kesimpulan akhir ditarik setelah pengumpulan data selesai dilakukan. Pengujian data dengan melakukan diskusi dengan rekan sejawat dan memeriksa data secara teliti sebelum ditarik kesimpulan

\section{HASIL DAN PEMBAHASAN}

Penggunaan internet sebagai media pemasaran online relatif mudah dilakukan karena dapat dijangkau oleh seluruh kalangan masyarakat dengan proses yang mudah dan menghemat waktu, tenaga, dan biaya. Pemasaran online merupakan salah satu media periklanan yang dapat membantu memasarkan produk secara efisien kepada konsumen. Cukup dengan melihat iklan yang ada di internet, konsumen dapat langsung mengetahui jenis dan varian telur asin yang dijual.

Adapun kemudahan bagi konsumen diantaranya yaitu log in ke smart toko, lalu buka E-Siatik, memilih produk dan melakukan transaksi. Transaksi dapat dilakukan tanpa batasan minimal order dan tentunya tanpa perlu mendatangi lokasi penjualan produk. Observasi lapangan menunjukkan aktivitas mitra driver dalam melayani order dan delivery berperan selama masa new normal seperti sekarang.

Para pedagang Telur asin yang memanfaatkan Pemasaran online diantaranya produk Itik master Brebes, Telur itik mentah, Telur asin Rebus, Telur asin Bakar, Telur asin Asap. Hasil penelitian menunjukkan bahwa waktu buka layanan dari pukul 08.00-20.00 WIB. Produk masing-masing merchant bisa beberapa jenis sesuai dengan dikehendaki. Jumlah dari produk 30 Pemasar yang ditampilkan pada layanan Online bervariasi satu sama lainnya yang dapat dilihat pada gambar 1 .

\section{Periklanan Online}

Periklanan online meliputi seluruh bentuk yang dibayar dari presentasi non personal dan promosi dari gagasan, barang, atau jasa yang disediakan oleh produsen yang dilakukan melalui internet/online (Ahyuna, Hamzah, \& HM, 2013) Proses periklanan secara online telah dilaksanakan dengan baik oleh beberapa produsen telur asin di Kabupaten Brebes walaupun tidak menjangkau seluruh produsen karena keterbatasan pengetahuan dan modal yang dimiliki.

Perlu dilakukan sosialisasi serta pendampingan untuk beberapa produsen yang masih melakukan pemasaran telur asin secara manual supaya produsen dapat lebih mudah menjual produk. Periklanan 
telur asin secara online dapat dijadikan solusi untuk mengatasi kesulitan dalam penjualan konvensional terutama bagi para produsen yang memiliki lokasi penjualan kurang strategis dan tidak terjangkau oleh calon konsumen yang lebih memilih membeli telur asin di sekitar Jalur Pantura.

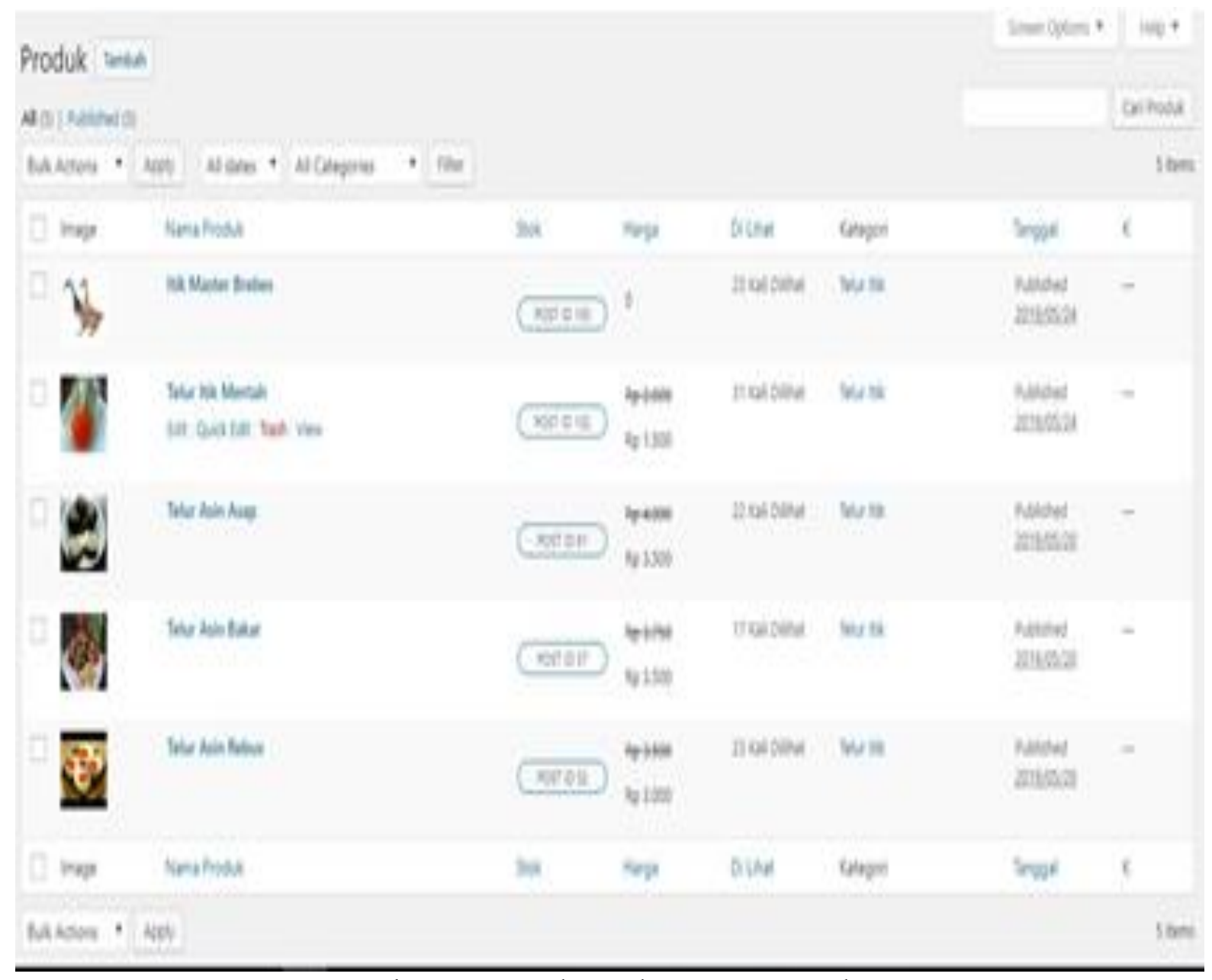

Gambar 1. Penjualan Telur Asin Via Online

Dari hasil data penelitian yang telah diperoleh dan dikaji dengan teori-teori dari para ahli menunjukkan bahwa periklanan online telah telah dilaksanakan dengan baik oleh informan dari penelitian ini. Iklan yang ditampilkan secara online menampilkan produk telur asin yang sesuai dengan keinginan konsumen. Hal tersebut dapat menarik minat konsumen karena tidak terdapat perbedaan antara telur asin yang diiklankan secara online dengan produk yang ada di display toko. Iklan yang dibuat dapat mewakili seluruh produk yang ada di toko. Sehingga dapat dikatakan bahwa produsen telah melakukan kegiatan periklanan yang merupakan bagian dari promotion mix secara efektif sehingga diharapkan dapet meningkatkan penjualan. 


\section{Sales Promotion}

Sales promotion merupakan suatu aktivitas yang dilakukan sebagai perangsang langsung yang menawarkan nilai tambah atau insentif untuk telur asin melalui internet secara online (Ahyuna et al., 2013). Sales promotion dapat meningkatkan penjualan produk serta dapat dilihat oleh seluruh konsumen di Indonesia sehingga produsen dapat mencapai target penjualan yang optimal.

Perbedaan sales promotion konvensional dengan sales promotion online adalah dalam durasi waktu promosi yang dapat dilakukan. Sales promotion secara konvensional harus melakukan promosi berulang kali dengan menguras waktu serta tenaga sedangkan sales promotion online, produsen hanya perlu memasarkan produk satu kali tapi calon konsumen dapat mengakses promosi tersebut berkali-kali melalui internet. Dapat dikatakan sales promotion online dilakukan untuk mencapai sasaran pemasaran dengan penggunaan biaya yang efektif dan dapat memberikan nilai tambah pada telur asin yang dipasarkan.

Kelemahan yang ditemui di lapangan terkait sales promotion secara online adalah keterbatasan kata-kata yang dapat diinformasikan oleh produsen karena telur asin yang dijual di pasaran relatif sama jenis dan bentuknya dengan milik pesaing. Perlu lebih banyak ide kreatif oleh produsen untuk meningkatkan nilai tambah telur asin produksinya. Salah satu cara adalah dengan memproduksi lebih banyak varian produk yang dapat dijadikan sebagai ciri khas dibandingkan jenis telur asin dari produk pesaing.

\section{Direct Marketing}

Direct marketing merupakan salah satu bagian dari promotion mix dalam penjualan produk melalui penawaran produk dengan disertai dengan pemberian jaminan atau garansi produk terhadap produk yang ditawarkan.

Telur asin merupakan produk makanan yang mempunyai umur simpan yang relatif singkat. Telur asin pun memiliki tingkat risiko yang tinggi apabila dijual melalui online karena tekstur yang mudah pecah sehingga perlu adanya direct marketing untuk meningkatkan kepercayaan konsumen. Direct marketing yang dilakukan pada produk telur asin dapat memberikan kepercayaan kepada konsumen terhadap produk yang dijual karena adanya jaminan apabila telur asin mengalami kerusakan dalam proses pengiriman.

\section{Personal Selling}

Personal selling merupakan salah satu bagian terakhir dalam promotion mix yang dilakukan oleh produsen dalam penjualan secara online. Personal selling memberikan ruang khusus antara produsen dan calon konsumen untuk dapat berkomunikasi melalui fasilitas yang diberikan oleh masing-masing produsen.

Produsen telur asin yang ada di Kabupaten Brebes yang dijadikan informan dalam penelitian ini telah melakukan personal selling dengan memberikan ruang dan waktu khusus untuk melayani konsumen yang membutuhkan informasi lebih dari produk telur asin yang akan dibeli. Calon konsumen dapat menghubungi produsen melalui fasilitas chat yang merupakan penghubung antara produsen dan calon konsumen. Personal selling merupakan salah satu bentuk respon dari produsen terhadap konsumen yang berminat untuk membeli produk mereka. 


\section{KESIMPULAN}

Berdasarkan penelitian yang dilakukan maka diambil kesimpulan bahwa produsen telur asin di Kabupaten Brebes telah melakukan system pemasaran dengan cara online dengan baik, dimana seluruh tahapan proses dalam kegiatan promotion mix. Produsen telah melakukan periklanan online, sales promotion, direct marketing, dan personal selling dengan baik. Para pemasar telor asin perlu menjaga dan meningkatkan model pemasaran online dengan individu yang terlatih, sehingga dapat memanfaatkan media online dengan maksimal diantaranya website, blog maupun sosial media.

\section{DAFTAR PUSTAKA}

Ahyuna, Hamzah, M. Djabir, \& HM, M. Najib. (2013). Pemanfaatan Internet Sebagai Media Promosi Pemasaran Produk Lokal Oleh Kalangan Usaha Di Kota Makassar. Jurnal Komunikasi KAREBA, 2(1), 30-40. https://doi.org/DOI: http:// dx.doi.org/10.31947/kjik.v2i1.346

Amrillah, Diyan Hayyu. (2013). Perkembangan Industri Telur Asin Di Kelurahan Limbangan Wetan Kecamatan Brebes Dan Pengaruhnya Terhadap Sosial Ekonomi Masyarakat Tahun 1980-2005.

Eva, Agustine. (2007). Persepsi Penggunaan Aplikasi Internet Untuk Pemasaran Produk Usaha Kecil Menengah. Seminar Nasional Aplikasi Teknologi Informasi, 2007(Snati), 19075022. https:// doi.org/1907-5022

Hasdar, Muhamad, Fera, Melly, \& Syaifulloh, Muhammad. (2019). Pemberdayaan Kelompok Bisnis Mahasiswa Berbasis IPTEK Melalui Program Agrofood Technopreneur. Jurnal SOLMA, 8(1), 73. https://doi.org/10.29405/ solma.v8i1.3206

Heru Mulyanto, Anna Wulandari. (2010). Penelitian: Metode dan Analisis. In CV. Agung Semarang.

Ikhwan, Syariefful, \& Nugroho, Bangun Satrio. (2019). Identifikasi Dampak Pembangunan Jalan Tol Pejagalan-Brebes Timur Terhadap Pemasaran Telur Asin Di Jalan Pantura Brebes ( Studi Kasus Umkm Telur Asin Kabupaten Brebes ). 12(1), 15-28. Retrieved from http:// ejournal.amikompurwokerto.ac.id/index.php/probisnis/article/view/817/495

Primatami, Anggraita, \& Primadhita, Yuridistya. (2020). Efisiensi UMKM Makanan Dengan Pendekatan Data Envelopment Analysis. Jurnal Pengembangan Wiraswasta, 22(01), 1. https://doi.org/10.33370/jpw.v22i01.388

Rais, Eko Budiharjo. (2019). Rancang Bangun E-Commerse sebagai Sarana Peningkatan Perekonomian Bagi Industri dan Menengah di Kabupaten Brebes. Smart Comp, 8(1), 610.

Setiawati, Ira. (2017). Pengaruh Strategi Pemasaran Online Terhadap Peningkatan Laba Umkm. Strategi Komunikasi Pemasaran, (20), 1-5. Retrieved from file:/ / C:/Users/BAYU/Downloads/Documents/263-760-1-PB.pdf

Sutedjo, Budi, \& Oetomo, Dharma. (2015). Pengaruh Web dalam Komunikasi Pemasaran untuk Meningkatkan Perhatian dan Ketertarikan Konsumen Online. Jurnal Eksplorasi 
Karya Sistem Informasi Dan Sains, 8(2), 94-106. Retrieved from http:/ / id.portalgaruda.org/index.php?ref=browse\&mod=viewarticle\&article=358193

Wandanaya, Anita B. (2012). Pengaruh Pemasaran Online Terhadap Keputusan Pembelian Produk. CCIT Journal, 5(2), 174-185. https:/ / doi.org/10.33050/ccit.v5i2.149 